\title{
GAMBARAN PERSEDIAAN OBAT DI APOTEK NIAS MEDIKA DENGAN ANALISIS ABC BERDASARKAN RESEP MASUK PERIODE JANUARI-MEI 2020
}

\author{
Vonny Nofrika $^{1}$, Ika Agustina ${ }^{2}$, Risca Priyani $^{3}$ \\ 1,2,3 Sekolah Tinggi Ilmu Kesehatan IKIFA
}

Email korespondensi: ika.agustina89.kai@gmail.com

\begin{abstract}
ABSTRAK
Apotek adalah sarana pelayanan kefarmasian tempat dilakukan praktik kefarmasian oleh Apoteker yaitu pembuatan termasuk pengendalian mutu sediaan farmasi, pengamanan, pengadaan, penyimpanan dan pendistribusi atau penyaluranan obat, pengelolaan obat, pelayanan obat atas resep dokter, pelayanan informasi obat, serta pengembangan obat, bahan obat dan obat tradisional Salah satu ruang lingkup dalam manajemen pelayanan kesehatan adalah manajemen logistik yaitu suatu bidang manajemen yang tugasnya khusus mengurusi logistik. Apotek nias medika tidak terdapat penyusunan khusus untuk pengadaan obat dengan metode tertentu sehingga sering terjadi kekosongan obat salah satunya untuk obat yang terdapat di resep dokter yang masuk ke apotek nias medika. Untuk itu perlu dilakukan pengendalian persediaan obat menggunakan metode tertentu salah satunya dengan menggunakan analisis ABC. Jenis penelitian adalah deskriptif dan kuantitatif, berdasarkan resep masuk dengan mencatat nama obat, jumlah obat, dan harga satuan obat kemudian diolah menggunakan analisa data selama bulan Januari-Mei 2020. Hasil penelitian menunjukan bahwa terdapat 160 jenis obat berdasarkan resep masuk ke apotek nias medika. Dengan 32 jenis (20\%) obat tergolong kelompok A yaitu dengan nilai investasi sebesar 69,68\% dengan obat laroton yang terdapat di posisi tertinggi. 47 jenis $(29,37 \%)$ obat tergolong kelompok B dengan nilai investasi sebesar 20,25\%. Sedangkan 81 jenis $(50,63 \%)$ obat tergolong kedalam kelompok $\mathrm{C}$ dengan total investasi 10,07\%.
\end{abstract}

Kata kunci: Manajemen Obat, Analisis ABC, Deskriptif kuantitatif 


\title{
DRUG INVENTORIES IN NIAS MEDIKA OVERVIEW WITH ABC ANALYSIS BASED ON RECIPES FOR THE PERIOD OF JANUARY-MAY 2020
}

\begin{abstract}
Pharmacy is a pharmaceutical service facility where pharmacy practices are carried out by pharmacists, namely manufacturing including quality control of pharmaceutical preparations, security, procurement, storage and distribution or distribution of drugs, drug management, prescription drug services, drug information services, and drug development services, drug ingredients and traditional medicine One of the scopes in the management of health services is logistics management, which is a field of management whose specific task is to deal with logistics. Pharmacy nias medika there was no specific arrangement for the procurement of drugs with certain methods so that often there is a vacuum of medicine one of which is for drugs contained in a doctor's prescription that goes to the nias medika pharmacy. For this reason, it was necessary to control drug inventory using certain methods, one of which was by using $A B C$ analysis. The type of research was descriptive and quantitative, based on the prescription entry by recording the name of the drug, the number of drugs, and the unit price of the drug and then processed using data analysis during January-May 2020. The results showed that there were 160 types of drugs based on prescription entry into the drugstore nias medika. With 32 types (20\%) drugs classified as group A with an investment value of $69.68 \%$ with laroton drugs which are in the highest position 47 types (29.37\%) drugs classified as group B with an investment value of $20.25 \%$, while 81 types $(50,63 \%)$ the drugs belong to group $C$ with a total investment of $10.07 \%$.
\end{abstract}

Keywords : Drug Management, ABC Analysis, quantitative descritive

\section{PENDAHULUAN}

Apotek adalah sarana pelayanan kefarmasian tempat dilakukan praktik kefarmasian oleh Apoteker. (Fajarini, 2018) Pekerjaan Kefarmasian adalah pembuatan termasuk pengendalian mutu sediaan farmasi, pengamanan, pengadaan, penyimpanan dan pendistribusi atau penyaluranan obat, pengelolaan obat, pelayanan obat atas resep dokter, pelayanan informasi obat, serta pengembangan obat, bahan obat dan obat tradisional. (Permenkes, 2017)
Salah satu ruang lingkup dalam manajemen pelayanan kesehatan adalah manajemen logistik yaitu suatu bidang manajemen yang tugasnya khusus mengurusi logistik.(Khuriyati, 2016) Manajemen logistik obat merupakan hal yang sangat penting bagi rumah sakit karena persediaan obat yang terlalu besar maupun terlalu sedikit akan membuat rumah sakit mengalami kerugian. Kerugian yang didapat berupa biaya persediaan obat yang membesar 
serta terganggunya kegiatan operasional pelayanan. (Stella Herliantine Febreani, 2016)

Metode analisis ABC merupakan metode pembuatan grup atau penggolongan berdasarkan perangkat nilai dari nilai tertinggi hingga terendah dan dibagi menjadi 3 kelompok besar yang disebut kelompok A (nilai investasi tinggi, B (nilai investasi sedang), dan C (nilai investasi rendah). Metode ini sangat berguna di dalam memfokuskan perhatian manajemen terhadap penentuan jenis barang yang paling penting dan perlu di prioritaskan dalam persediaan. (Utari, 2014)

Sebuah penelitian yang dilakukan di salah satu Rumah Sakit di kota Bandung menunjukan bahwa Rumah sakit dapat menghemat sekitar 56,93\% biaya jika menerapkan sistem pengendalian terhadap kelebihan stok. Perlu diperhatikan bahwa pemilihan sistem pengendalian persediaan obat bukan proses yang sederhana karena manajemen persediaan selain terkait biaya dan keuntungan rumah sakit juga berpengaruh terhadap kualitas layanan dan penjaminan keselamatan pasien. (Monika Noviena Susanto, 2019)

Sebuah penelitian yang telah dilakukan Apotek Yuhistira menyediakan 203 item obat dengan 135 item obat diresepkan dan 68 item obat tidak diresepkan, dalam pengadaannya selama enam bulan dikeluarkan biaya sebesar Rp. 91.386.739 dan untuk obat kelompok A memakan biaya sebesar Rp 63.327.681 dengan persentase 69,30\% dari total biaya keseluruhan, namun dengan jumlah item obat yang paling sedikit jika dibandingkan dengan kelompok obat B dan C. Sehingga dapat disimpulkan bahwa obat-obat kelompok A benar-benar dibutuhkan dalam pelayanan obat untuk pasien di klinik medhis Yudhistira, sehingga persediaannya harus tetap ada. (Uswatun Hasanah Linnisaa, 2014)

Apotek nias medika tidak terdapat penyusunan khusus untuk pengadaan obat dengan metode tertentu sehingga sering terjadi kekosongan obat karena tidak pernah dilakukan pengecekan obat yang rutin tiap bulan nya sehingga jika ada obat yang sisa sedikit tidak diketahui. Dari hasil uji pendahuluan yang dilakukan bulan Oktober sampai Desember di apotek nias medika terdapat 12 item obat yang stok nya sedang kosong dari resep yang masuk ke apotek nias medika sehingga harus dibuatkan copy resep untuk pembelian obat di apotek lain. Data obat kosong tersebut adalah fastor $20 \mathrm{mg}$, candesartan $16 \mathrm{mg}$, diprosta cream, acarbose $50 \mathrm{mg}$, atorvastatin $20 \mathrm{mg}$, lansiclav tablet, fenolip $300 \mathrm{mg}$, prospide tablet, lapifed tablet, moprin, dexyclav tablet, dan dom tablet. Dari data obat kosong tersebut apotek mengalami kerugian degan total omset yang hilang sebesar $\mathrm{Rp} 3.241 .000$ dan obat tergolong kepada kategori A,B dan C.

Berdasarkan latar belakang di atas, maka akan dilakukan penelitian tentang gambaran persediaan obat di apotek nias medika berdasarkan resep masuk dengan analisis $\mathrm{ABC}$ periode JanuariMei 2020.

https://doi.org/10.33759/jrki.v3i2.140 


\section{METODE PENELITIAN}

\section{MATERIAL}

Resep dokter, pulpen, buku, komputer

\section{Rancangan Penelitian}

Populasi dalam penelitian ini adalah semua resep dokter yang terdapat di Apotek Nias Medika. Teknik pengambilan sampel yang digunakan adalah total sampling dengan jumlah lembar resep sebanyak 2.376 lembar selama 5 bulan.

HASIL DAN PEMBAHASAN Hasil Kelompok Obat berdasarkan Analisis ABC

Berdasarkan penelitian yang sudah dilakukan pada bulan Januari-Mei 2020 terdapat 160 jenis obat paten maupun generik yang terdapat dalam resep yang
Data dikumpulkan dengan mencatat nama obat, jumlah obat dan harga obat, kemudian dimasukan kerumus menggunakan analis $\mathrm{ABC}$ dan membuat persentase dari hasil tersebut. Seluruh data yang telah ditetapkan dari penelitian dikumpulkan, kemudian disusun dan dikelompokan serta diolah dengan menggunakan Microsoft excel. Hasil penelitian ini akan disajikan dan dijabarkan dalam bentuk tabel hasil.

masuk kedalam Apotek Nias Medika dengan total omset sebesar Rp. Rp 302.381.100. Dengan nilai omset tertinggi pada kelompok A sebesar 69,68\%. Data tersebut dapat dilihat pada Tabel I.

Tabel I. Persentase Omset Obat dengan Analisis ABC

\begin{tabular}{cccccc}
\hline No. & $\begin{array}{c}\text { Kelompok } \\
\text { obat }\end{array}$ & $\begin{array}{c}\text { Jumlah } \\
\text { item obat }\end{array}$ & $\begin{array}{c}\text { Persentase item } \\
\text { obat }(\%)\end{array}$ & $\begin{array}{c}\text { Total } \\
\text { omset } \\
(\mathrm{Rp})\end{array}$ & $\begin{array}{c}\text { Persentase } \\
\text { nilai omset } \\
(\%)\end{array}$ \\
\hline 1. & $\mathrm{~A}$ & 32 & 20 & $210,715,600$ & 69,68 \\
2. & $\mathrm{~B}$ & 47 & 29,37 & $61,228,100$ & 20,25 \\
3. & $\mathrm{C}$ & 81 & 50,63 & $30,437,400$ & 10,07 \\
\hline & Total & 160 & 100 & $302,381,100$ & 100 \\
\hline
\end{tabular}

\section{Item obat kelompok A}

Hasil perhitungan analisis $\mathrm{ABC}$ didapatkan kelompok A terdapat 32 item obat atau $20 \%$ dari total item obat. Berikut ini adalah 20 item obat teratas kelompok A. 


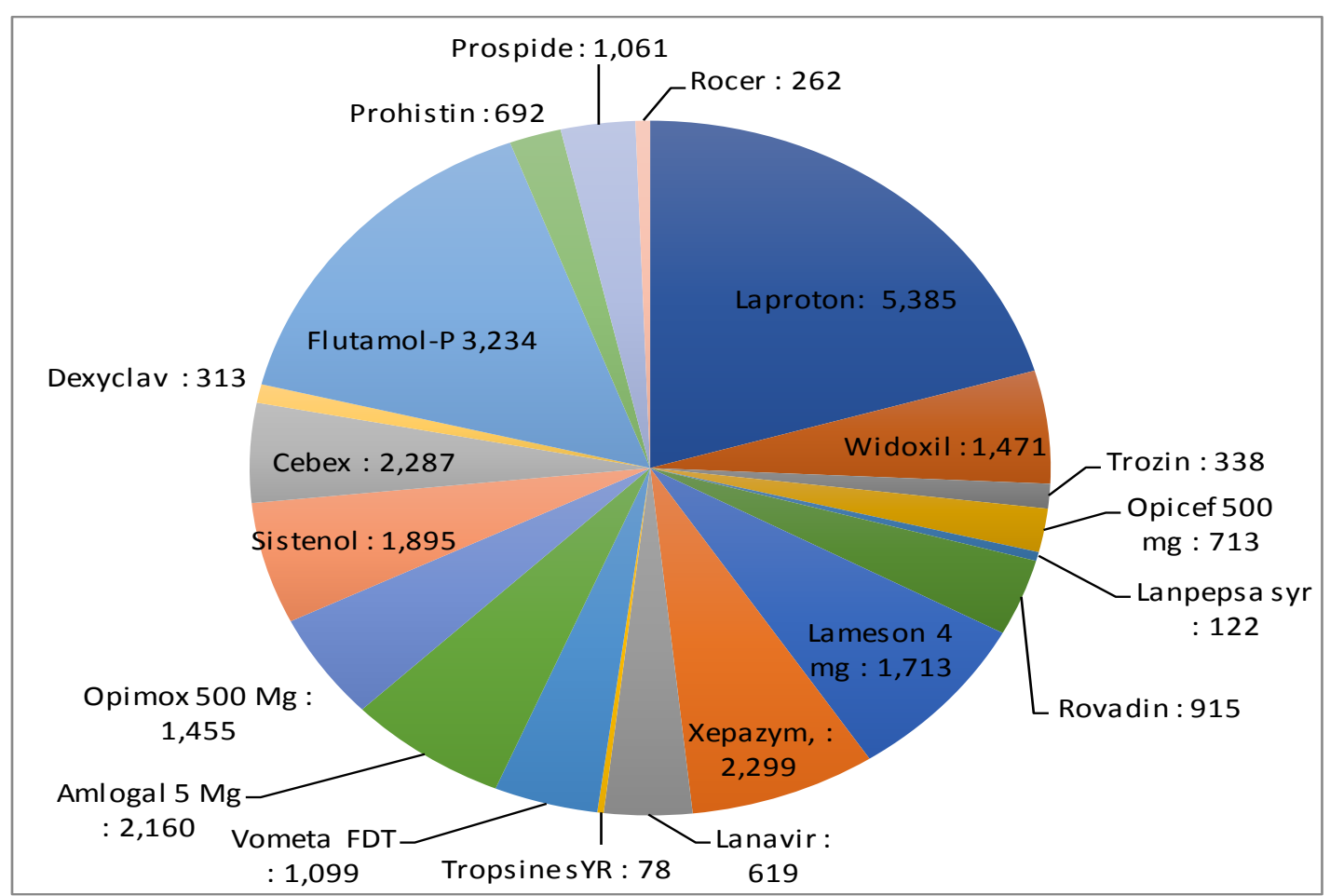

Gambar I. Grafik Hasil Penelitian Obat kelompok A Selama Januari-Mei 2020

berdasarkan analisis $\mathrm{ABC}$ obat dengan nilai omset tertinggi yaitu laproton 30 mg. obat ini merupakan obat merek dagang dengan komposisi lansoprazole $30 \mathrm{mg}$ yang di produksi oleh tempo scan pacific. Laproton digunakan untuk tukak lambung aktif dan tukak lambung duodenum,refluks esophagitis erosive yang refrakter dan sindrom zollinger Ellison. Dosis laproton disesuaikan dengan diagnose seperti untuk tukak duodenum 30mg/hari selama 4 minggu. (IAI, 2010)

Prevalensi penderita gastritis di seluruh Rumah Sakit di Indonesia sebanyak 218.500 kasus. Prevalensi penderita gastritis di Provinsi Riau adalah sebanyak 31,12 persen. Penderita gastritis yang disebabkan oleh stres adalah sebanyak 8,72 persen. Negara yang angka kejadian gastritis paling tinggi yaitu Amerika dengan persentase mencapai 47 persen, India 43 persen,dan Indonesia mencapai peringkat ketiga dengan 40,8 persen. (Widiyanto \& Khaironi, 2014)

Sedangkan obat dengan nilai omset terendah untuk kelompok A yaitu opicef $250 \mathrm{mg}$ syrup. Opicef merupakan obat antibiotic golongan sefalosporin. Merupakan obat paten yang di produksi oleh perusahaan otto. Mengandung sefadroksil monohidrat setara dengan sefadroksil $250 \mathrm{mg}$ untuk sediaan syrup kering forte. Mempunyai indikasi untuk infeksi saluran nafas atas dan bawah, kulit jaringan lunak, dan artritis seftik. Dengan dosis anak 25-50mg/KgBB/hari dibagi dalam 2 dosis terbagi. (IAI, 2010)

Hal ini menggabarkan bahwa golongan obat antibiotik dan obat gangguan pencernaan dan golongan antivirus memiliki nilai investasi yang sangat tinggi walaupun penggunaannya ada beberapa yang rendah dibandingkan 
dengan obat golongan B atau C seperti tropsine syrup dimana total pemakaian dalam 5 bulan hanya 78 botol. Dengan demikian kelompok A merupakan barang dengan jumlah fisik kecil dengan nilai investasi yang besar, sehingga obat tersebut harus memiliki kontrol persediaan yang lebih ketat, pencatatan harus lebih akurat dan lebih ketat secara periodik setiap satu bulan.

(Dr. Akhmad, 2018)

\section{Item obat kelompok B}

Hasil perhitungan analisis $\mathrm{ABC}$ didapatkan kelompok B terdapat 47 item obat atau 29,37\% dari total item obat. Berikut ini adalah 20 item obat teratas kelompok B.

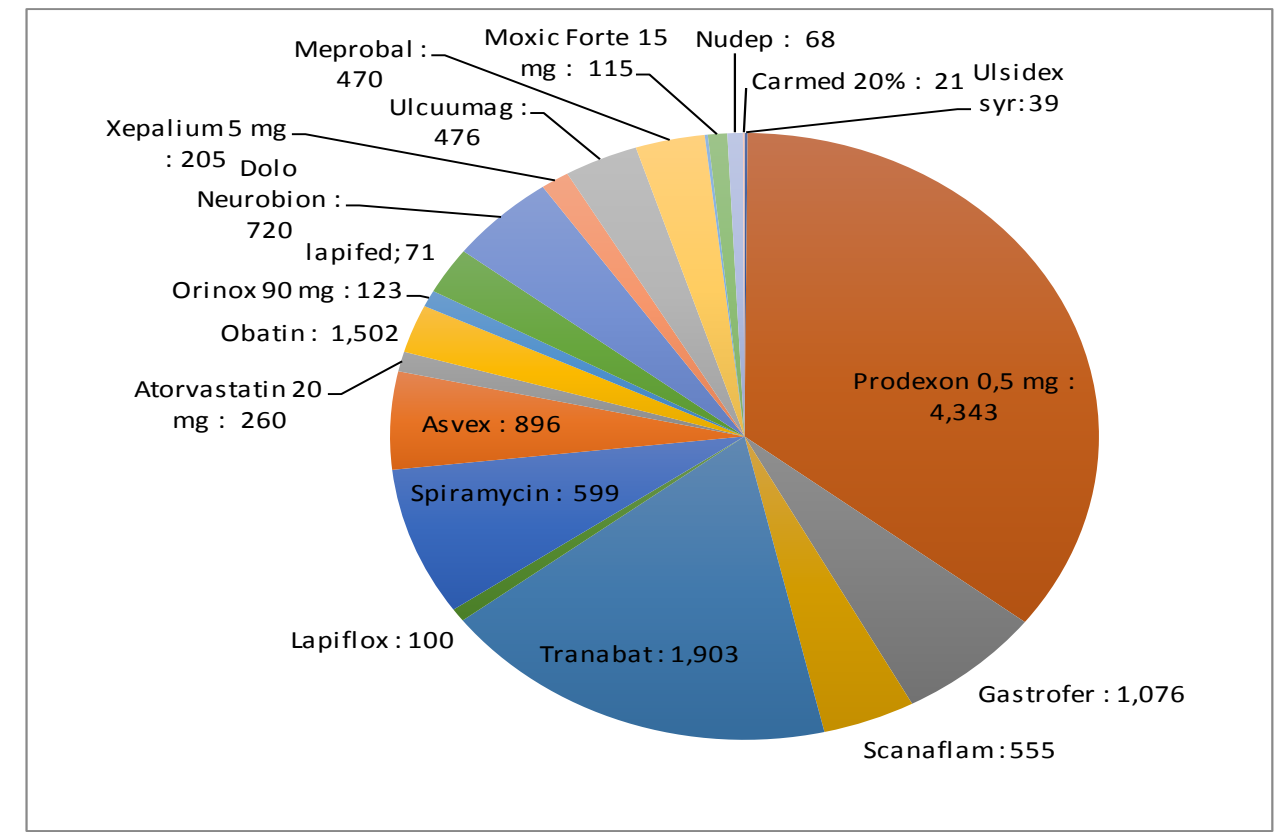

Gambar II. Grafik Hasil Penelitian Obat kelompok B Selama Januari-Mei 2020

obat kelompok B urutan tertinggi yaitu ulsidex syrup. Ulsidex syrup mengandung zat aktif sukralfat. Sukralfat merupakan obat golongan antiulcerant dengan manfaat mengobati tukak lambung dan ulkus duodenum, mengobati gastritis akut, dan mencegah pendarahan saluran cerna. Obat ini bekerja dengan membentuk lapisan pada bagian yang luka dan melindunginya dari asam lambung yang dapat memperlambat penyembuhan. Mengkonsumsi obat sukralfat dalam keadaan perut kosong, 1 jam sebelum makan atau sesuai anjuran dokter. (IAI, 2010)

Obat selanjutnya yaitu obat dengan urutan terakhir dalam obat hasil kelompok B dengan nama scanovir cream. Merupakan obat yang di produksi oleh tempo scan pacific dengan komposisi tiap gram asiklovir $5 \%$. Obat ini tergolomg dalam obat topical kulit golongan antivirus. Asiklovir mempunyai indikasi untuk infeksi herpes zoster, infeksi virus herpes simplek pada kulit dan selaput lendir,dll. (IAI, 2010) 
Pada kelompok B ini, jenis penggolongan efek farmakologinya sudah beragam. Kelompok B merupakan obat-obatan dengan jumlah investasi yang sedang, sehingga obat yang tergolong kelompok B memerlukan perhatian yang cukup penting setelah kelompok A dapat dilakukan monitoring dengan komputer. perlu dilakukan pengawasan fisik yang dilakukan setiap 3-6 bulan sekali dengan dasar perencanaan menggunakan penggunaan yang lalu agar obat kelompok B tersedia dalam jumlah yang cukup. (Utari, 2014)

\section{Item obat kelompok $\mathbf{C}$}

Hasil perhitungan analisis $\mathrm{ABC}$ didapatkan kelompok $\mathrm{C}$ terdapat 81 item obat atau 50,63\% dari total item obat. Berikut ini adalah 20 item obat teratas kelompok $\mathrm{C}$.

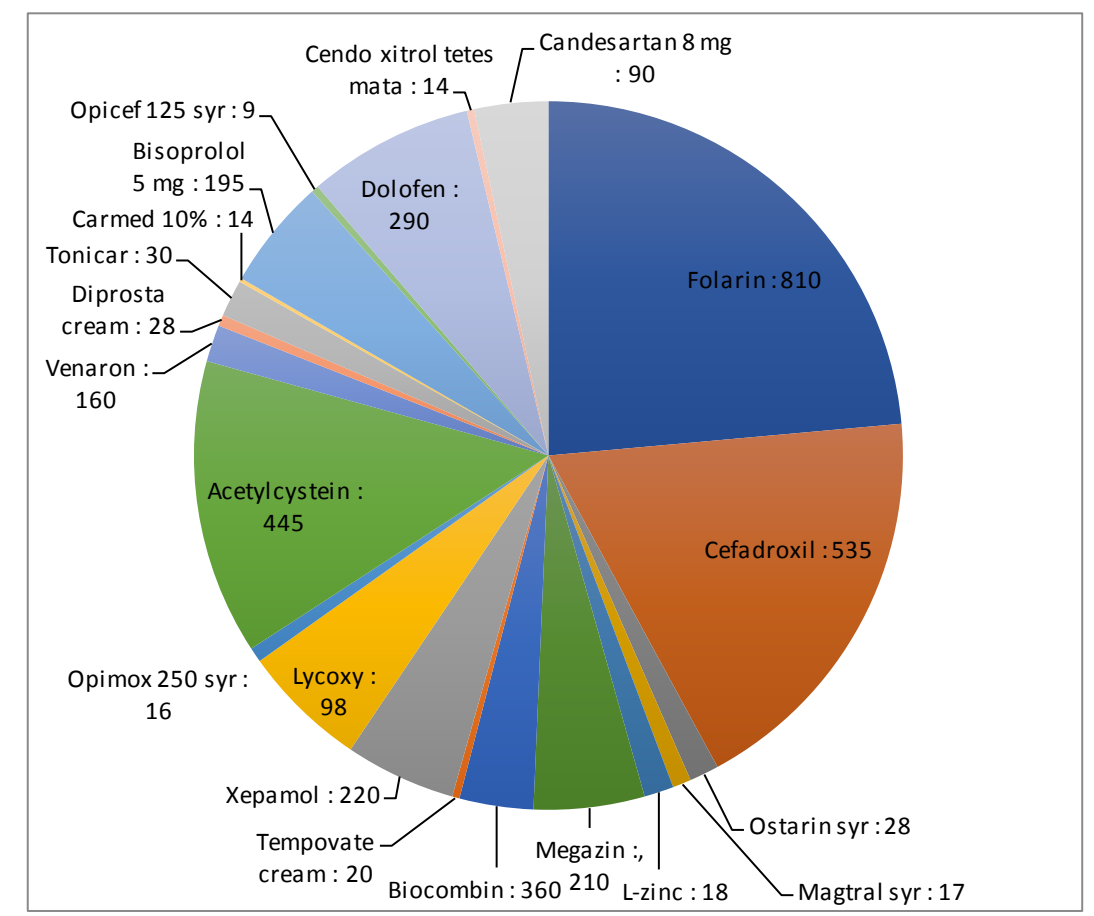

Gambar III. Grafik Hasil Penelitian Obat kelompok C Selama Januari-Mei 2020

Kelompok obat $\mathrm{C}$ merupakan kelompok dengan nilai omset yang rendah dari total omset obat secara keseluruhan di Apotek Nias Medika. Kelompok C merupakan barang dengan jumlah fisik yang besar namun nilai omset yang kecil yang masuk kedalam Apotek Nias Medika. Dari hasil penelitian obat yang terdapat di kelompok C merupakan obat dengan jumlah sedikit pemakaian sehingga menghasilkan total omset yang rendah. Sehingga dapat dilakukan pengawasan fisik obat dan dapat dilakukan 6 sampai 12 bulan sekali untuk mencegah terjadinya obat kadaluwarsa dan kekosongan obat. (Utari, 2014)

Hasil penelitian obat berdasakan analisis $\mathrm{ABC}$ obat dengan kelompok $\mathrm{C}$ pertama yaitu folarin. Folarin 
merupakan obat dengan zat aktif asam folat $1000 \mathrm{mcg}$. Asam folat merupakan obat yang mempengaruhi darah yaitu anemia. Asam folat berfungsi untuk anemia mengaloblastik dan makrositik akibat defisiensi asam folat. Mempunyai kontra indikasi hipersensitif, pemberian jangka panjang untuk beberapa penderita defisiensi kobalamin yang tidak diobati. Untuk dosis disesuaikan dengan diagnosa seperti untuk defisiensi asam folat dosis awal 0,25- $1 \mathrm{mg} /$ hari sampai terdapat respon klinis, sedangkan untuk suplemen diet yaitu 0,1-1 gr. (IAI, 2010)

Obat kelompok C selanjutnya yaitu obat dengan obat terakhir yang terdapat di kelompok C yaitu vitamin B6. Merupakan obat vitamin dan mineral. Mempunyai indikasi untuk membantu menambah suplemen vitamin b6. Dengan dosis 3 kali sehari 1 tabletr 10 $\mathrm{mg}$ atau 2 kali sehari 1 tabletr $25 \mathrm{mg}$. (IAI, 2010)

Kelompok C memiliki jumlah item obat terbesar dibandingkan kelompok A dan $\mathrm{B}$, hal ini menunjukan bahwa $50,63 \%$ item obat pada pengadaan bulan januari-mei 2020 yang masuk kedalam kelompok C memiliki nilai investasi yang kecil, sehingga perlu dilakukan penghapusan untuk item obat yang pemakaiannya sangat sedkit dan memiliki persamaan obat (mee-too) pada kelompok A dan B. (Utari, 2014) Pada suatu studi menghasilkan suatu kesimpulan bahwa system pengadaan obat dengan menggunakan model pareto $\mathrm{ABC}$ dinilai sesuai dengan kebutuhan pengguna. Sistem tersebut dibuat dalam bentuk aplikasi desktop dengan database Management System MySQL. Sistem tersebut dapat mendukung pengambilan keputusan pengadaan obat di Apotek. (Nurwulandari \& Rosa, 2013)

\section{KESIMPULAN}

Kesimpulan dari penelitian ini adalah : Berdasarkan analisis ABC berdasarkan resep masuk di Apotek Nias Medika, didapatkan hasil 160 jenis obat. Kelompok A merupakan barang dengan jumlah fisik kecil dengan nilai investasi yang besar, sehingga obat tersebut harus memiliki kontrol persediaan yang lebih ketat, pencatatan harus lebih akurat dan lebih ketat secara periodik setiap satu bulan.

\section{UCAPAN TERIMAKASIH}

Pada kesempatan ini, peneliti ingin mengucapkan terima kasih kepada berbagai pihak yang telah membantu terwujudnya penelitian ini :

1. Ketua Sekolah Tinggi Ilmu Kesehatan IKIFA

2. Apotek Nias Medika

\section{DAFTAR PUSTAKA}

Dr. Akhmad, S. M. (2018). Manajemen Operasi; Teori dan Aplikasi dalam Dunis Bisnis. Bogor: Azkiya Publishing.

Fajarini, H. (2018). Implementasi Peraturan Menteri Kesehatan Ri No.73 Tahun 2016 Tentang Standar Pelayanan Kefarmasian Di Apotek. Parapemikir J Ilm Farm, 7(7), 260.

Febreani, S. H., \& Chalidyanto, D. (2016). Pengelolaan Sediaan Obat pada Logistik Farmasi https://doi.org/10.33759/jrki.v3i2.140 
Rumah Sakit Umum Tipe B di Jawa Timur. Jurnal Administrasi Kesehatan Indonesia, 4(2), 136145.

IAI. (2010). ISO: Informasi Spesialite Obat Indonesia Vol.45 - 2010 s/d 2011 (Vol. 45). Jakarta: ISFI.

Izzatul, K. L. (2016). Pengendalian Persediaan Obat Kemoterapi Melalui Pendekatan Analisis ABC Indeks Kritis di Ruang Pencampuran Instalasi Farmasi RSUP Dr. Mohammad Hoesin Palembang Tahun 2015. Jurnal Arsi, 3(1), 66-67.

Linnisaa, U. H., \& Wati, S. E. (2014). Rasionalitas Peresepan Obat Batuk Ekspektoran dan Antitusif di Apotek Jati Medika Periode Oktober - Desember 2012. Indonesian Journal on Medical Science, 1(1), 30-39.

Permenkes. (2017). Sterkwerkende Geneesmiddelen Ordonanntie, Staatsblad 1949:419. Jakarta: Permenkes RI.
Susanto, M. N., \& Permanasari, V. Y. (2019). Penerapan Metode ABC Indeks Kritis dalam Pengelolaan Persediaan Obat di Instalasi Farmasi Rumah Sakit XYZ Pekanbaru, Riau Tahun 2018. Jurnal Administrasi Rumah Sakit Indonesia, 5(2), 72-84.

Utari, A. (2014). Cara Pengendalian Persediaan Obat Paten Dengan Metode Analisis ABC, Metode Economic Order Quantity (EOQ), Buffer Stock Dan Reorder Point (ROP) Di Unit Gudang Farmasi RS Zahirah. Jakarta: Fakultas Kedokteran UIN Syarif Hidayatullah.

Widiyanto, J., \& Khaironi, M. (2014). Hubungan Antara Tingkat Stres dengan Kejadian Gastrisis (Study di Puskesmas Harapan Raya Pekanbaru). Photon Jurnal Sain dan Kesehatan, 5(1), 2932. 